\title{
Comparing Astrocytic Cell Lines that Are Inhibitory or Permissive for Axon Growth: the Major Axon-Inhibitory Proteoglycan Is NG2
}

\author{
Penny S. Fidler, ${ }^{1}$ Katrin Schuette, ${ }^{2}$ Richard A. Asher, ${ }^{1}$ Alexandre Dobbertin, ${ }^{2}$ Suzanne R. Thornton, ${ }^{3}$ \\ Yolanda Calle-Patino, ${ }^{3}$ Elizabeth Muir, ${ }^{1}$ Joel M. Levine, ${ }^{4}$ Herbert M. Geller, ${ }^{3}$ John H. Rogers, ${ }^{1}$ \\ Andreas Faissner, ${ }^{2,5}$ James W. Fawcett ${ }^{1}$ \\ ${ }^{1}$ Department of Physiology and Medical Research Council, Cambridge Centre for Brain Repair, University of Cambridge, \\ Cambridge CB2 3EG, United Kingdom, 2Department of Neurobiology, University of Heidelberg, 69120 Heidelberg, \\ Germany, ${ }^{3}$ Department of Pharmacology, University of Medicine and Dentistry of New Jersey, Robert Wood Johnson \\ Medical School, Piscataway, New Jersey 08854, ${ }^{4}$ Department of Neurobiology and Behavior, State University of New \\ York, Stony Brook, New York, 11794, and ${ }^{5}$ Laboratoire de Neurobiologie du Développement et de la Régénération \\ (LNDR, UPR 1352), Centre de Neurochimie du Centre National de la Recherche Scientifique, F-67084 Strasbourg \\ Cedex, France
}

\begin{abstract}
Astrocytes, oligodendrocytes, and oligodendrocyte/type 2 astrocyte progenitors (O2A cells) can all produce molecules that inhibit axon regeneration. We have shown previously that inhibition of axon growth by astrocytes involves proteoglycans. To identify inhibitory mechanisms, we created astrocyte cell lines that are permissive or nonpermissive and showed that nonpermissive cells produce inhibitory chondroitin sulfate proteoglycans (CS-PGs). We have now tested these cell lines for the production and inhibitory function of known large CS-PGs. The most inhibitory line, Neu7, produces three CS-PGs in much greater amounts than the other cell lines: NG2, versican, and the CS-56 antigen. The contribution of NG2 to inhibition by the cells was tested using a function-blocking antibody. This allowed increased growth of dorsal root ganglion (DRG) axons over Neu7 cells and matrix and greatly increased the proportion of cortical axons able to cross from permissive A7 cells onto
\end{abstract}

inhibitory Neu7 cells; CS-56 antibody had a similar effect. Inhibitory fractions of conditioned medium contained NG2 coupled to CS glycosaminoglycan chains, whereas noninhibitory fractions contained NG2 without CS chains. Enzyme preparations that facilitated axon growth in Neu7 cultures were shown to either degrade the NG2 core protein or remove CS chains. Versican is present as patches on Neu7 monolayers, but DRG axons do not avoid these patches. Therefore, NG2 appears to be the major axon-inhibitory factor made by Neu7 astrocytes. In the CNS, NG2 is expressed by O2A cells, which react rapidly after injury to produce a dense NG2-rich network, and by some reactive astrocytes. Our results suggest that NG2 may be a major obstacle to axon regeneration.

Key words: axon regeneration; chondroitin sulfate; NG2; extracellular matrix; proteoglycans; versican
Injury to the CNS generally results in the formation of a glial scar, a predominantly astrocytic structure that can constitute a no-go zone for regenerating axons. Reactive astrocytes upregulate their synthesis of many cell surface, secreted, and matrix molecules, but various lines of evidence point toward chondroitin sulfate proteoglycans (CS-PG) as being the major source of inhibitory molecules in the glial scar. For instance, Davies et al. (1997) showed that neurons grafted atraumatically into white matter tracts of adult rats were able to regenerate their axons. However, in some animals, axon growth failed, and in these animals the graft was enclosed by a ring of chondroitin sulfate. A different approach has been to remove reactive astrocytes from the brain by implanting a nitrocellulose filter. These cells express high

\footnotetext{
Received Nov. 4, 1998; revised July 23, 1999; accepted Aug. 2, 1999.

This work was supported by The Wellcome Trust (to P.S.F. and R.A.A.); the International Spinal Research Trust, Action Research, and Association de Recherche sur le Cancer (to A.D.); Fondation de la Recherche Medicale, Deutsche Forschungsgemeinschaft (Grant Fa 159/11-1), and Centre National de la Recherche Scientifique (to A.F.); and National Institutes of Health Grant NS25168 (to H.M.G.).

Drs. Fidler and Schuette contributed equally to this work.

Correspondence should be addressed to James Fawcett, Department of Physiology, Downing Street, University of Cambridge, Cambridge CB2 3EG, United Kingdom.

Copyright (C) 1999 Society for Neuroscience $\quad 0270-6474 / 99 / 198778-11 \$ 05.00 / 0$
}

levels of CS-PG, are inhibitory to axon growth, and can be made more permissive to growth by treatment with glycosaminoglycan (GAG)-degrading enzymes (McKeon et al., 1991). Many proteoglycans, particularly those carrying chondroitin sulfate, have been shown to be inhibitory to neurite outgrowth in vitro (Snow et al., 1990; Dou and Levine, 1994). Based on their distribution in the embryo, it has also been suggested that CS-PGs act as molecular barriers, preventing the growth of axons into inappropriate regions (Snow et al., 1990; Snow and Letourneau, 1992; Pindzola et al., 1993; Landolt et al., 1995).

As another approach toward determining which of the cell surface, diffusible, and matrix molecules present in glial scars might be critical to the inhibition of axon growth, we developed a panel of astrocyte cell lines displaying a range of abilities to promote growth (Geller and Dubois-Dalcq, 1988; Fok-Seang et al., 1995; Powell et al., 1997). The most inhibitory cell line, Neu7, was inhibitory to dorsal root ganglion (DRG), retinal, and cortical axons, whereas the A7 cell line was the most permissive. Analysis of the differences between the cell lines demonstrated that the inhibitory properties of the Neu7 cell line were primarily caused by their production of CS-PGs. Disruption of proteoglycan synthesis and enzymatic removal of the chondroitin sulfate made the cells and their extracellular matrix more permissive to axon 
growth, reduced the laminin-blocking activity of their conditioned medium (CM) (Smith-Thomas et al., 1994, 1995), and reduced their ability to form boundaries that repel axons (Powell et al., 1997). Importantly, it was also possible to increase axon growth through three-dimensional cultures of primary astrocytes by disrupting proteoglycan sulfation with chlorate (SmithThomas et al., 1995).

We have now screened these astrocyte cell lines for those large proteoglycans known to be expressed in the CNS to ascertain which are differentially expressed and might be responsible for the inhibition. We report that several CS-PGs are differentially expressed, but on the basis of functional assays, we believe that NG2 provides an important component of the inhibitory activity. This structurally unique CS-PG has been shown to be a potent inhibitor of neurite outgrowth in vitro (Dou and Levine, 1994) and is also highly expressed within the glial scar (Levine, 1994).

\section{MATERIALS AND METHODS}

\section{Astrocyte cell lines}

The A7 cell line was derived from cultured new-born rat optic nerve, immortalized with the SV40 large T antigen (Geller and Dubois-Dalcq, 1988). The remaining three GFAP-positive cell lines originated from cultures of neonatal rat cerebral cortex (Fok-Seang et al., 1995). Neu7 was immortalized by the nеu oncogene, whereas T27A1 and T34.2 were immortalized by the temperature-sensitive form of the SV40 large T antigen. Cultures were maintained in DMEM containing $10 \%$ fetal calf serum (FCS) and 1\% penicillin-streptomycin-fungizone (PSF). Where stated, Neu7 was grown in $10 \%$ horse serum, which made them even less permissive to neurite outgrowth (J. W. Fawcett, unpublished observation).

\section{Sample preparation for SDS-PAGE}

Supernatant. Cells in a $25 \mathrm{~cm}^{2}$ flask were grown to confluency in serum, rinsed three times in DMEM, and then incubated in exactly $2.5 \mathrm{ml}$ of serum-free medium (DMEM containing 1\% insulin-transferrin-selenium-BSA-linoleic acid (ITS+) (Collaborative Research, Paisley, Scotland). After $2 \mathrm{~d}$, the serum-free CM was collected and concentrated 10 -fold in a centricon-50 (Millipore, Bedford, MA) in the presence of a cocktail of protease inhibitors (Complete; Boehringer Mannheim). Each track received one-fifth of the concentrated CM $(50 \mu \mathrm{l})$.

Metabolic labeling of cell lines. Cells $\left(10^{6}\right)$ of each line were labeled overnight by addition of $250 \mathrm{mCi}$ of $\mathrm{Na}_{2}{ }^{-35} \mathrm{SO}_{4}$ into the medium. The medium was taken off, the cells were lysed with $1 \%$ Triton X-100 buffer, and one-tenth of the supernatant or cell extract was loaded per lane after addition of reducing sample buffer. Proteins were separated in a $4-10 \%$ gel, and the dried gel was exposed to film.

Supernatant proteoglycan fractions. Confluent monolayers were incubated in serum-free medium. After $2 \mathrm{~d}$, the conditioned media were collected, centrifuged at $100,000 \times g$ for $1 \mathrm{hr}$, and applied to a Q-Sepharose anion exchange column (Amersham Pharmacia Biotech, Amersham, UK). The column was washed with sodium acetate buffer (containing 0.15 or $0.5 \mathrm{M} \mathrm{NaCl}$ ), and a proteoglycan fraction was eluted with $1.0 \mathrm{M} \mathrm{NaCl}$. This fraction was dialyzed against $50 \mathrm{~mm}$ ammonium bicarbonate, lyophilized, and resuspended in PBS. The glycosaminoglycan content of the fractions was determined using the Blyscan assay (Biocolor, Belfast, UK). The inhibitory activity of each fraction was assayed by growing DRGs in $35 \mathrm{~mm}$ tissue culture dishes precoated overnight with $1.5 \mathrm{mg}$ laminin and $50 \mathrm{gm}$ of either the 0.5 or $1.0 \mathrm{M}$ fraction. The DRGs were grown for $2 \mathrm{~d}$ in serum-free medium (DMEM, $1 \%$ ITS +, and $20 \mathrm{~mm}$ Ara-C) containing $50 \mathrm{mg}$ of the appropriate fraction per dish. DRGs were scored to have grown axons if more than three axons had grown for one explant diameter or more.

Detergent lysates. Confluent cultures in $25 \mathrm{~cm}^{2}$ flasks were washed three times with $0.05 \mathrm{M}$ Tris and $0.15 \mathrm{M} \mathrm{NaCl}, \mathrm{pH} 7.4$, and removed with a cell scraper. The cells were centrifuged, and the pellet was resuspended in $0.25 \mathrm{ml}$ of the same buffer containing $1 \%$ Triton X-100 and the cocktail of protease inhibitors and incubated on ice for $1 \mathrm{hr}$. The suspension was centrifuged at $13,000 \mathrm{rpm}$ for $10 \mathrm{~min}$ at $4^{\circ} \mathrm{C}$. The protein content of the detergent lysate was determined using the Coomassie plus protein assay reagent (Pierce, Rockford, IL), and the volumes were adjusted to give equal loading to each lane.
Membrane fractions. Cells were lysed from the culture dish in a hypotonic buffer, homogenized using a 27 gauge needle, and layered on top of a sucrose step gradient (50 and 5\% sucrose in PBS). After centrifugation for $10 \mathrm{~min}$ at $28,000 \mathrm{rpm}$, membranes were collected from the interface between the sucrose cushions and washed twice in PBS. Protein content was determined using the Bio-Rad (Hercules, CA) Protein Assay.

\section{GAG lyase digestion}

Samples of $0.05 \mathrm{ml}$ were digested with $0.02 \mathrm{U}$ of protease-free chondroitinase $\mathrm{ABC}(\mathrm{ChABC})$ (Boehringer Mannheim) for $2.5 \mathrm{hr}$ at $37^{\circ} \mathrm{C}$.

\section{Biosynthetic labeling of cell cultures and immunoprecipitation}

Cell lines were grown to confluency in 6-cm-diameter Petri culture dishes. For overall biosynthetic labeling, medium was changed to methionine-cysteine- and $\mathrm{Na}_{2} \mathrm{SO}_{4}$-free DMEM for $1 \mathrm{hr}$. Thereafter, 200 $\mu \mathrm{Ci} / \mathrm{ml}{ }^{35} \mathrm{~S}$-methionine-cysteine (Amersham Pharmacia Biotech translabel) and $50 \mu \mathrm{Ci} / \mathrm{ml} \mathrm{Na}_{2}{ }^{35} \mathrm{SO}_{4}$ were added to the cultures for the times indicated. For biosynthetic labeling of sulfated carbohydrate groups, cultures were incubated overnight with $50 \mu \mathrm{Ci} / \mathrm{ml}{ }^{35} \mathrm{SO}_{4}$ in $\mathrm{Na}_{2} \mathrm{SO}_{4}$-free DMEM supplemented with $1 \%$ fetal calf serum. At the end of the labeling period, supernatants were collected and supplied with a mixture of protease inhibitors (EDTA and iodoacetamide at $5 \mathrm{~mm}$, PMSF at 1 $\mathrm{mM}$, soybean trypsin inhibitor at $10 \mu \mathrm{g} / \mathrm{ml}$, and aprotinin, leupeptin and pepstatin, all at $5 \mu \mathrm{g} / \mathrm{ml}$ ) and $0.1 \%$ BSA (w/v). Cell monolayers were washed twice with PBS $(1 \times)$ and detergent solubilized in $1 \mathrm{ml}$ of ice-cold solubilization buffer $[0.15 \mathrm{M} \mathrm{NaCl}, 20 \mathrm{~mm}$ Tris-HCl, 1 mM EGTA, $0.5 \%$ (v/v) Nonidet-40 (NP-40), 0.1\% (w/v) BSA, and 0.05\% (w/v) NaN3, pH 7.4] supplemented with protease inhibitors as indicated above. After 10 min on ice, cells were scraped off the culture dish, transferred to tubes, and kept on ice for another $30 \mathrm{~min}$. Supernatants and detergent extracts were cleared by consecutive rounds of centrif ugation at $800 \times g, 4^{\circ} \mathrm{C}$, for $10 \mathrm{~min}$ to remove large debris or cell nuclei, and subsequently at $100000 \times g, 4^{\circ} \mathrm{C}$, for $45 \mathrm{~min}$. For determination of incorporated activity, $50 \mu \mathrm{l}$ aliquots from detergent extracts or culture supernatants were incubated with TCA $(20 \% \mathrm{w} / \mathrm{v})$ for $1 \mathrm{hr}$ on ice. Precipitates were collected by centrifugation and washed twice with TCA $(10 \% \mathrm{w} / \mathrm{v})$, and the resulting pellets were dried, dissolved in preheated SDS sample buffer, boiled for $5 \mathrm{~min}$, and finally quantified in a g-scintillation counter. For immunoprecipitation, $1 \mathrm{ml}$ aliquots of biosynthetically labeled detergent-solubilized cell extracts or culture supernatants were precleared by incubation with $120 \mu \mathrm{l}$ of preswollen Sepharose-protein A conjugate $(10 \% \mathrm{v} / \mathrm{v}$; Amersham Pharmacia Biotech) for $30 \mathrm{~min}$ to remove nonspecific binding to Sepharose-protein A beads. After removal of the Sepharose beads by centrifugation, the aliquots were mixed with $80 \mu \mathrm{g}$ of $\mathrm{IgG}$ fraction of polyclonal anti-NG2 antibodies and incubated overnight at $4^{\circ} \mathrm{C}$. The aliquots were subsequently incubated for $1 \mathrm{hr}$ with $120 \mu \mathrm{l}$ of preswollen Sepharose-protein A conjugate. Thereafter, the beads were washed by four cycles of centrif ugation and resuspension in buffers of decreasing salt concentration. Finally, the beads were resuspended in $100 \mu \mathrm{l}$ of SDS sample buffer and boiled for $5 \mathrm{~min}$ at $100^{\circ} \mathrm{C}$ (Faissner et al., 1994). A $50 \mu \mathrm{l}$ aliquot of the resulting extract was counted in a g-scintillation counter, whereas the remaining $50 \mu \mathrm{l}$ were resolved on a $4-10 \%$ gradient SDS-polyacrylamide gel. After the run, gels were fixed in $10 \%(\mathrm{v} / \mathrm{v})$ acetate and $30 \%(\mathrm{v} / \mathrm{v})$ methanol in water, vacuum-dried, and exposed to a phosphoimager (Fuji x-BAS 1000) plates at room temperature.

\section{Western blot analysis}

Polypeptides were separated in 5\% SDS-polyacrylamide gels (without a reducing agent) and transferred to nitrocellulose (Hybond-C pure; Amersham) for $\sim 16 \mathrm{hr}$ at $0.15 \mathrm{~A}$. The blots were blocked for $1 \mathrm{hr}$ in either $5 \%$ non-fat dried milk in TBS- $0.05 \%$ Tween 20 or TBS-Tween 20 alone and then incubated for $2 \mathrm{hr}$ in primary antibody. Various antibodies were used, and their concentrations and sources are in Table 1 . All subsequent washes were six times for $5 \mathrm{~min}$, and incubations were performed in TBS- $-0.05 \%$ Tween 20 . The blots were then incubated with biotinylated anti-mouse Ig or biotinylated anti-rabbit Ig (Amersham) for $1 \mathrm{hr}$, washed as before, incubated with alkaline phosphatase-avidin D (1:1000; Vector Laboratories, Burlingame, CA) for $1 \mathrm{hr}$, and washed, and reactive bands were visualized using a substrate of 5-bromo-4-chloro-3-indoylphosphate and nitroblue tetrazolium (Vector Laboratories). Alternatively, bands were visualized using an HRP-conjugated secondary antibody, followed by chemiluminescence used in accordance with the supplier's instructions (ECL kit; Amersham). 


\begin{tabular}{|c|c|c|c|c|c|c|c|}
\hline Antigen & Antibody & Host species & Source & $\begin{array}{l}\text { Working } \\
\text { dilution }\end{array}$ & ChABC & Reducing & Gel \% \\
\hline NG2 & $\mathrm{a}-\mathrm{NG} 2$ & Rabbit & J. Levine & 1:1000 & Yes & No & $5 \%$ \\
\hline Versican & $12 \mathrm{C} 5$ & Mouse IgG1 & R. A. Asher & $1: 1000$ & Yes & No & $5 \%$ \\
\hline Neurocan & 1D1 & Mouse IgG1 & U. Rauch & $1: 100$ & Yes & & \\
\hline Brevican & $\mathrm{Pc}$ & Rabbit & E. Gundelfinger & 1:1000 & Yes & No & $5 \%$ \\
\hline CD44 & OX-50 & Mouse IgG1 & ECACC & $1: 50$ & Yes & No & $5 \%$ \\
\hline \multicolumn{8}{|l|}{$\mathrm{CS} /$} \\
\hline DS-PG & MO-225 & Mouse IgM & Seikagaku & 1:1000 & No & Yes & $5 \%$ \\
\hline CS-PG & CS-56 & Mouse IgM & Sigma & $1: 500$ & No & No & $5 \%$ \\
\hline $\mathrm{KS}$ & $5 \mathrm{D} 4,2 \mathrm{D} 3$ & Mouse & B. Caterson & $1: 200$ & No & & \\
\hline CS-4 & 2B6 & Mouse & B. Caterson & $1: 200$ & Yes & & \\
\hline CS-6 & $3 \mathrm{~B} 3$ & Mouse & B. Caterson & $1: 200$ & Yes & & \\
\hline HABR & $5 \mathrm{C} 4$ & Mouse & B. Caterson & $1: 200$ & No & & \\
\hline APP & $22 \mathrm{C} 11$ & Mouse IgG & G. Multhaup & & & & \\
\hline
\end{tabular}

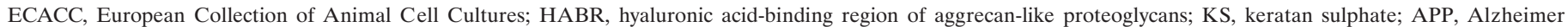
precursor protein.

\section{ELISA}

The wells of a Microtest flexible assay plate (Falcon) were coated overnight with $0.2 \mathrm{ml}$ of cell supernatant. The plates were washed three times with PBS and blocked for $1 \mathrm{hr}$ with $4 \%$ non-fat dried milk in PBS $-0.05 \%$ Tween 20 . The primary antibody was applied in blocking buffer for $2 \mathrm{hr}$ at $37^{\circ} \mathrm{C}$ and the HRP-conjugated secondary antibody for $1 \mathrm{hr}$ at $37^{\circ} \mathrm{C}$. Plates were developed with 2,2'-azino-di-[3-ethylbenzthiazoline sulfonate], and the reaction was stopped by the addition of SDS to a final concentration of $0.2 \%$. The reaction product was quantified with an ELISA reader at $405 \mathrm{~nm}$.

\section{Immunocytochemistry}

Cells were seeded onto poly-L-lysine-coated glass coverslips and grown in DMEM containing $10 \%$ FCS. They were fixed in $4 \%$ paraformaldehyde and blocked in PBS containing 1\% goat serum and 1\% BSA, and the primary antibody was added for 1-2 hr. Generally, polyclonal antibodies were visualized using a fluorescent secondary antibody, whereas a biotinylated secondary antibody was used for monoclonal antibodies. For versican, it was necessary to fix in cold $\left(-20^{\circ} \mathrm{C}\right)$ methanol. For double labeling, live cells were labeled for versican and CS-56, fixed in methanol, and then labeled with a rabbit anti-neurofilament antibody (Genosys, The Woodlands, TX).

\section{Axon growth assays}

Intact DRGs from neonatal rats were plated onto confluent monolayers of Neu7 cells, as described by Fok-Seang et al. (1995), in the presence of either the polyclonal anti-NG2 antibody $(0.4 \mathrm{mg} / \mathrm{ml})$ or the same concentration of a rabbit polyclonal antibody to laminin. The cultures were grown in media (DMEM containing 10\% horse serum and 1\% PSF) supplemented with $10 \mathrm{ng} / \mathrm{ml}$ nerve growth factor. Twenty-four hours later, the cultures were fixed in cold methanol, and the neurites were visualized using the anti-neurofilament monoclonal 3A10 (Developmental Studies Hybridoma Bank, Iowa City, IA). Neurite length was estimated as the mean of the 10 longest axons, measured from the edge of the explant to the growth tip. The total number of axons from each DRG was counted: when fasciculation was present, the number of axons in each fascicle was estimated by following the fascicle out to the margin of the halo of growing axons and counting the axons dissociating from the fascicle. Total outgrowth was the length multiplied by the number of axons. Results were from three separate assays. Neu7 matrix was made by water lysis of cell monolayers for $20 \mathrm{~min}$, followed by washing in HBSS. DRGs were plated on the matrix in ITS + serum-free medium with NGF, with and without $0.2 \mathrm{mg} / \mathrm{ml}$ anti-NG2, and growth was assayed $24 \mathrm{hr}$ later. DRGs were counted as having grown axons if more than three axons had grown for more than one explant diameter.

\section{Generation of cellular boundaries}

Cellular boundaries were generated as we have described previously (Powell et al., 1997) by first plating A7 cells on poly-L-lysine-coated coverslips at a density of $3 \times 10^{4}$ cells per coverslip in DMEM-10\% FCS. Twenty-four hours later, A7 or Neu7 cells were labeled with the vital dyes DiI or PKH26 and fast blue $(0.1 \mu \mathrm{g} / \mathrm{ml}$; Sigma, St. Louis, MO) and plated at a density of $3 \times 10^{3}$ cells per coverslip onto subconfluent A7 cells. Using this procedure, the cells formed a mixed monolayer within $24 \mathrm{hr}$. The monolayers are referred to as A7/A7 and A7/Neu7.

\section{Cell culture and boundary assay}

Cerebral cortical neuronal cultures were prepared as described by Morris and Geller (1996). Briefly, timed-pregnant Sprague Dawley rats were killed at embryonic day 17 , and embryos were removed by cesarean section and placed in cold basal medium Eagle's containing $0.02 \mathrm{M}$ sodium-HEPES (BME-HEPES). The cortical hemispheres were dissected from each embryonic brain in cold BME-HEPES. Meningeal tissues were carefully removed from the tissue and incubated in BMEHEPES containing $0.025 \%$ trypsin (type-II) and $0.1 \%$ type-IV collagenase for $30 \mathrm{~min}$ at $37^{\circ} \mathrm{C}$. The reaction was halted with $0.025 \%$ soybean trypsin inhibitor and $0.05 \%$ DNase I, and the tissue was gently triturated several times through a fire-polished Pasteur pipette. The cells were centrifuged at $1000 \times g$ at $4^{\circ} \mathrm{C}$ for $5 \mathrm{~min}$, filtered through sterile $40 \mu \mathrm{m}$ mesh. Cortical neurons were resuspended in DMEM supplemented with $10 \%$ FCS, penicillin $(50 \mu \mathrm{g} / \mathrm{ml})$, and streptomycin $(50 \mathrm{U} / \mathrm{ml})$.

For the boundary assay, cerebral cortical neurons were plated on confluent A7/A7 or A7/Neu7 cellular substrates at a density of $3.5 \times 10^{4}$ cells per well and allowed to adhere for 3-4 hr. After adherence to the cellular substrates, $0.2 \mathrm{mg} / \mathrm{ml}$ rat anti-mouse immunoglobulin G1 (IgG1) (Cappel, West Chester, PA), rabbit anti-neurofilament 200 (Sigma) at $1: 1000,0.2 \mathrm{mg} / \mathrm{ml}$ of $\mathrm{NG} 2$, or $1.2 \mathrm{gm} / \mathrm{ml} \mathrm{CS}-56$ antibody were added. Sixteen hours after the addition of the IgG1 or NG-2 antibody, neurons on cellular substrates were labeled with the vital dye 5(6)carboxyfluorescein diacetate, which intensely stains the soma and processes of living neurons (Petroski and Geller, 1994). One hundred neurites per coverslip were assessed as to their stopping, turning, or crossing upon encountering the A7/A7 or A7/Neu 7 cellular boundaries, as described previously (Powell et al., 1997). Each experimental condition consisted of three coverslips, and the experiments were repeated three times.

\section{RESULTS}

\section{Neu7 cells produce inhibitory proteoglycans}

We first analyzed the proteoglycan synthesis by Neu 7 and A7 cell lines. The cells were grown for $12 \mathrm{hr}$ in the presence of $\mathrm{Na}_{2} 35 \mathrm{SO}_{4}$, and the cell lysate and $\mathrm{CM}$ were analyzed by SDSPAGE. Because the majority of sulfate is incorporated into proteoglycans, this method provides a rough estimate of overall proteoglycan synthesis in the cell lines. Figure 1 shows that Neu7 incorporates much more sulfate than A7. The radiolabel was 


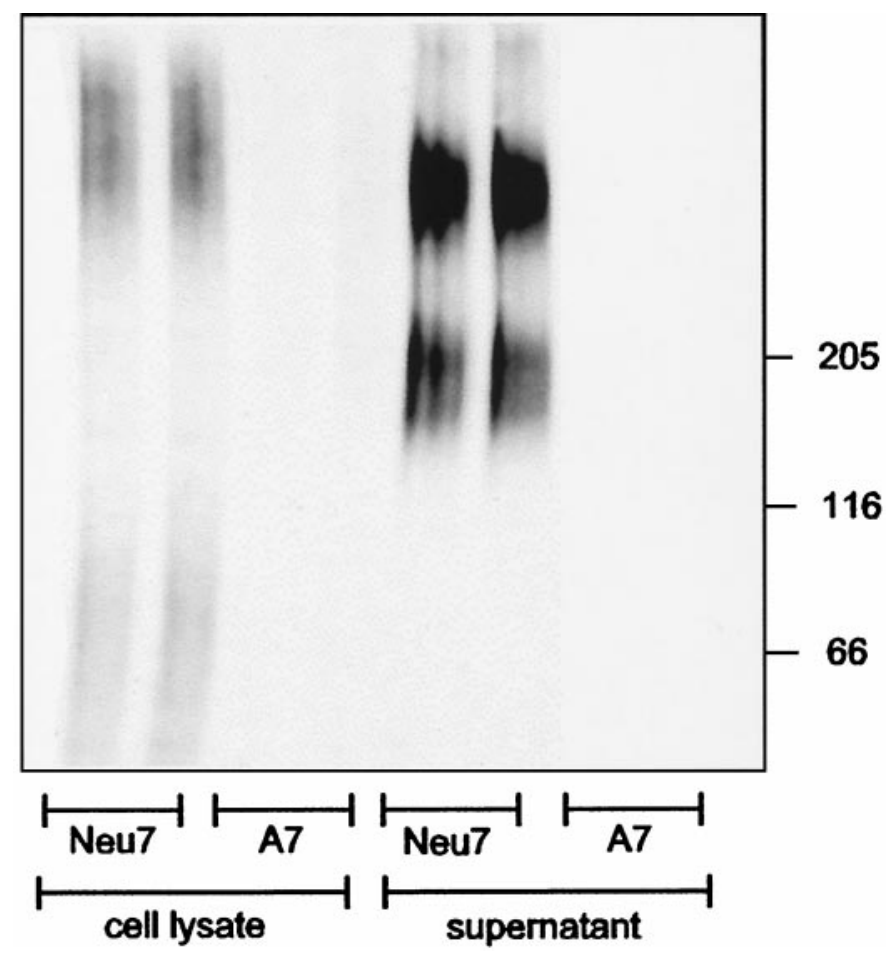

Figure 1. Sulfate incorporation into cell lysate (left 4 tracks) and supernatant (right 4 tracks) from Neu7 and A7 cells after growing the cells in the presence of $\mathrm{Na}_{2}{ }^{35} \mathrm{SO}_{4}$ overnight. Neu7 cells incorporate much more sulfate than A7 into both types of sample.

incorporated into species migrating at $80-90 \mathrm{kDa}$ and greater than $350 \mathrm{kDa}$ in the cell lysate, and into polydisperse material migrating at $140-180$ and $350-500 \mathrm{kDa}$ in the CM. Neu7 and A7 serum-free supernatants contain the same amount of total protein, measured by the Bio-Rad assay at $1.2 \mathrm{mg} / \mathrm{ml}$.

We have shown previously that the inhibitory activity in conditioned medium from the Neu7 line is found in fractions from an anion exchange column that contain sulfate (Smith-Thomas et al., 1994). In the present study, we fractionated CM from both Neu7 and A7 cells on an anion exchange column, and the fractions eluting with $0.5 \mathrm{M} \mathrm{NaCl}$ and $1.0 \mathrm{M} \mathrm{NaCl}$ were collected. We then tested the ability of the fractions to block the neurite outgrowthpromoting properties of laminin from explants of neonatal rat DRGs. The $0.5 \mathrm{M}$ fractions from both A7 and Neu7 were not inhibitory to DRG outgrowth on laminin. However, the $1.0 \mathrm{M}$ fraction from Neu7, but not from A7, was growth-inhibitory (Fig. 2). The glycosaminoglycan content of the $1 \mathrm{~m}$ fractions was tested by a modified dimethylene blue assay (Blyscan; Biocolor); the Neu7 $1 \mathrm{M}$ fraction contained $2.8 \mathrm{mg} / \mathrm{ml}$, and the A7 $1 \mathrm{~m}$ fraction contained $0.9 \mathrm{mg} / \mathrm{ml}$. Neu 7 cells therefore produce more proteoglycan overall than A7, and the fraction of Neu7 supernatant eluting at $1.0 \mathrm{M} \mathrm{NaCl}$ contains the inhibitory activity.

\section{Expression of CNS proteoglycans by cell lines}

We screened A7 and Neu7 cells for differential expression of a variety of individual proteoglycans and chondroitin sulfate epitopes that have been described in the CNS. These results are shown in Table 2 (Table 2). The major differences we detected were much greater expression of NG2, versican, and the proteoglycans recognized by the CS-56 antibody in Neu7 cells.

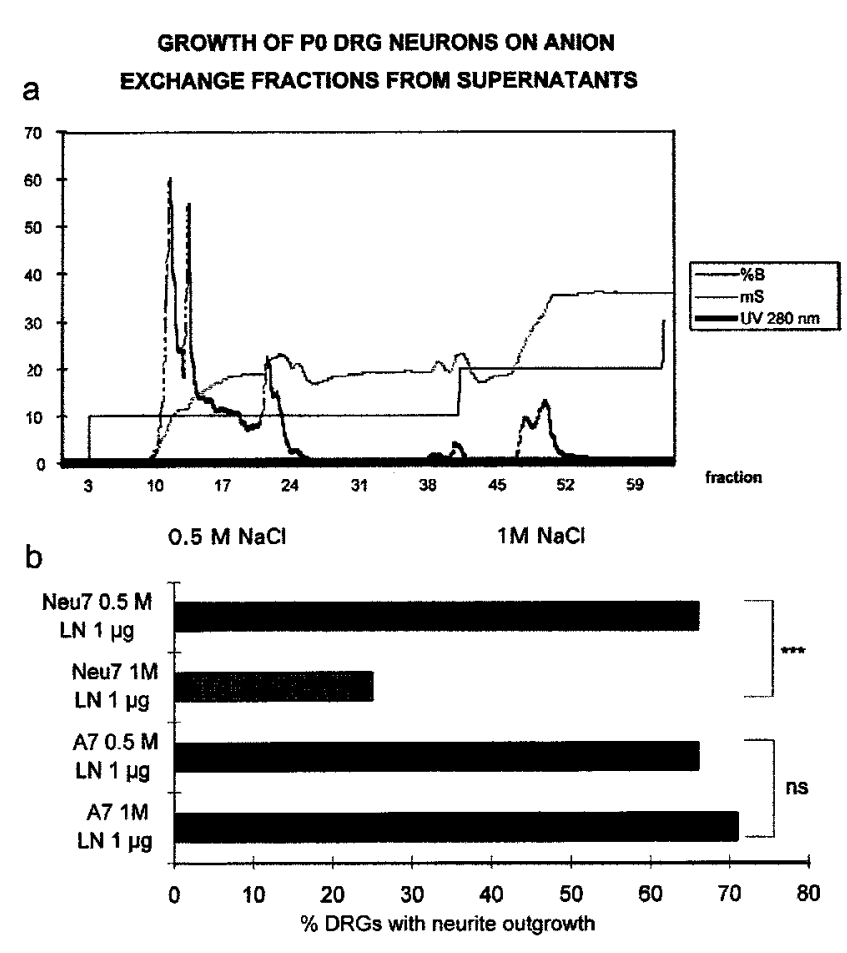

Figure 2. Fractionation of Neu7 conditioned medium on an anion exchange column $(a) . \% B$ is salt concentration, $m S$ is the conductivity, and $U V 280 \mathrm{~nm}$ is the UV absorption. The UV absorption curve shows that two absorption peaks come off the column, one at $0.5 \mathrm{M} \mathrm{NaCl}$ and one at $1 \mathrm{M} \mathrm{NaCl}$. These two fractions and equivalent fractions from the A7 cell line were tested for their ability to inhibit axon growth on a laminin substrate. In $b$, the proportion of DRGs that grew axons on the four test substrates is shown. Only the $1 \mathrm{~m}$ fraction from Neu7 was inhibitory.

\section{Expression of the NG2 proteoglycan}

Because our initial screen showed that NG2 was one of the proteoglycans that was made in large amounts by Neu7 but not by A7, we investigated its expression further.

NG2 consists of a $300 \mathrm{kDa}$ core protein bearing GAG chains composed entirely of chondroitin sulfate and is found in three forms: the full-length $300 \mathrm{kDa}$ transmembrane form; a $290 \mathrm{kDa}$ form released from the cell surface by proteolytic cleavage; and a $275 \mathrm{kDa}$ membrane-associated form, which is also subject to proteolytic cleavage but which remains associated with the cell surface (Nishiyama et al., 1995). NG2 was detectable in detergent lysates and in cell culture supernatant only from Neu7 cells and not from any of the three more permissive cell lines A7, 27A1, and T34.2 (results for A7 and Neu7 are shown in Fig. $3 a$ ). The highly concentrated 1.0 and $0.5 \mathrm{M} \mathrm{NaCl}$ fractions of $\mathrm{A} 7$ and $\mathrm{Neu} 7$ supernatants were subjected to SDS-PAGE and examined using Western blots with anti-NG2 antibody. As shown in Figure $3 a$, there was a large amount of NG2 in the Neu7 $1 \mathrm{M}$ fraction and very little in the A7 $1 \mathrm{M}$ fraction, seen as a band of $270-300 \mathrm{kDa}$ (our largest size marker was $205 \mathrm{kDa}$ ). Detection of NG2 in the $1.0 \mathrm{M}$ fraction from A7, but not in the culture supernatant from which it was derived, is presumably a concentration effect, reflecting low levels of NG2 production by A7 cells, which is just detectable in highly enriched samples. As shown in Figure $3 b$, the $\mathrm{NG} 2$ band from the Neu7 $1.0 \mathrm{M}$ fraction could only be seen on blots in which the fraction had been digested with ChABC. In the $0.5 \mathrm{M}$ fractions, there was a large amount of NG2 in the Neu7 samples and a smaller amount in the A7 samples. These fractions produced bands at $\sim 300 \mathrm{kDa}$ without previous digestion with 
Table 2. Expression of proteoglycans

\begin{tabular}{|c|c|c|c|c|c|c|c|c|}
\hline & \multicolumn{4}{|c|}{ Supernatant } & \multicolumn{4}{|c|}{ Cells detergent extract } \\
\hline & \multicolumn{2}{|c|}{ ELISA } & \multicolumn{2}{|c|}{ Western blot } & \multicolumn{2}{|c|}{ Immunofluorescence } & \multicolumn{2}{|c|}{ Western blot } \\
\hline & A7 & Neu7 & A7 & Neu7 & A7 & Neu7 & A7 & Neu7 \\
\hline NG2 & - & +++ & - & +++ & - & +++ & - & ++ \\
\hline Versican & & & - & +++ & & +++ & - & - \\
\hline Neurocan & - & - & - & - & - & - & - & - \\
\hline Brevican & & & - & - & - & - & - & - \\
\hline Perlecan & +++ & +++ & & & ++ & ++ & ++ & ++ \\
\hline $\mathrm{CS}-56 \mathrm{mAb}$ & + & + & - & + & + & +++ & ++ & ++ \\
\hline 5D4, 2D3(a-KS) & + & ++ & & & + & + & + & + \\
\hline $2 \mathrm{~B} 6(\mathrm{a}-\mathrm{C}-4-\mathrm{S})$ & + & + & & & ++ & ++ & + & + \\
\hline $3 \mathrm{~B} 3(\mathrm{a}-\mathrm{C}-6-\mathrm{S})$ & + & + & & & + & + & + & ++ \\
\hline MO-225 (a-CS) & & & - & - & & & & \\
\hline $5 \mathrm{C} 4 \mathrm{a}-\mathrm{HABR}$ & ++ & +++ & & & + & ++ & - & - \\
\hline
\end{tabular}

- , Nondetectable;,+++ , or +++ indicates increasing levels of expression. HABR, Hyaluronic acid-binding region of aggrecan-like proteoglycans; KS, keratan sulphate.

a

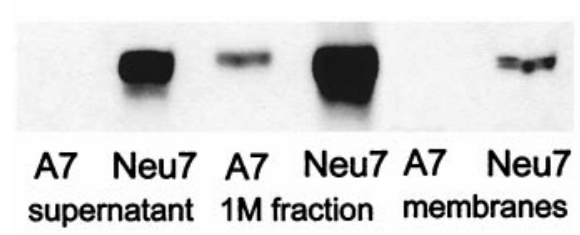

b

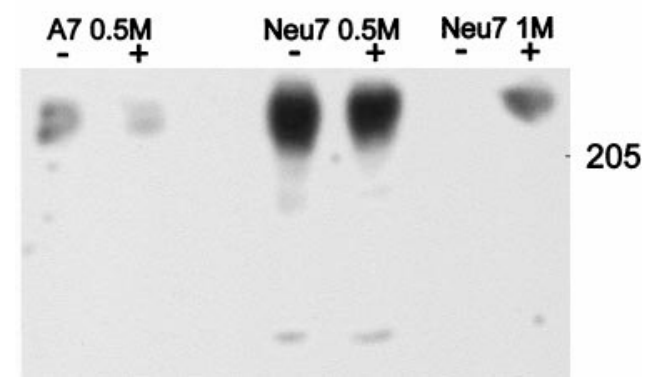

Figure 3. a, Production of NG2 by A7 and Neu7 cells. In A7 cells, NG2 is not detectable in the supernatant or membrane fraction. It is only detectable in small amounts in the highly concentrated $1 \mathrm{~m}$ fraction from ion exchange fractionation. Neu7 produces large amounts of NG2 in cell surface and released forms, seen in the detergent lysate and culture supernatant samples. These samples were digested with chondroitinase ABC. $B, N G 2$ in fractions from anion exchange. The fractions from both $\mathrm{A} 7$ and Neu7 coming off the column at $0.5 \mathrm{M} \mathrm{NaCl}$ contain NG2, which forms a discrete band in the absence of chondroitinase $\mathrm{ABC}$ digestion, and therefore has little or no GAG chain attached. There is a large amount of NG2 in the $1 \mathrm{M}$ fraction from Neu7, but this cannot be seen as a discrete band unless it is digested with chondroitinase $\mathrm{ABC}$, indicating that all the NG2 in this fraction carries GAG chains.

ChABC, and chondroitinase digestion made no difference to the appearance of the bands. These results suggest that Neu7 makes large amounts of $\mathrm{NG} 2$, much of which is linked to CS GAG chains and therefore interacts strongly with the anion exchange column and comes off at $1 . \mathrm{OM} \mathrm{NaCl}$, and some of which is not linked to GAG chains and therefore interacts weakly with the column and comes off at $0.5 \mathrm{M} \mathrm{NaCl}$. The A7 line makes much smaller amounts of NG2, and the greater part of this is not linked to GAG chains and therefore comes off at $0.5 \mathrm{M} \mathrm{NaCl}$. Immunocytochemistry revealed that most, but not all, Neu7 cells were NG2-positive in subconfluent cultures (Fig. 4a,b); in fully confluent monolayers, staining was more uniform, with most cells expressing NG2. Axons will grow sparsely on Neu7 monolayers. In fully confluent monolayers that will support axon growth, the NG2 is fairly evenly distributed, so it is not possible to test whether axons preferentially avoid regions of higher NG2 expression (Fig. 4c,d). A7 monolayers did not stain above background (data not shown).

\section{Proportion of total protein and total proteoglycan represented by NG2}

The Western blot analysis clearly suggested an enhanced expression of NG2 with attached GAG chains in the Neu7 compared with the A7 cell line. To obtain an estimate of the relative proportion of the proteoglycan in reference to the overall protein and proteoglycan synthesis in the respective cell lines, biosynthetic labeling and immunoprecipitation experiments were performed. When overall protein synthesis was evaluated using ${ }^{35} \mathrm{~S}$ methionine-cysteine, both Neu7 and A7 showed comparable anabolic activity with $153.4 \times 10^{6} \mathrm{cpm}$ versus $192.7 \times 10^{6} \mathrm{cpm}$ incorporated activity per dish in the detergent extracts of the monolayers, respectively (Figs. 5, 6). In contrast, there were marked differences in ${ }^{35} \mathrm{~S}$-sulfate incorporation, with $\sim 2 \times 10^{6}$ $\mathrm{cpm}$ in the detergent extract and $8 \times 10^{6} \mathrm{cpm}$ in the culture supernatant of Neu7, whereas A7 achieved only $0.5 \times 10^{6} \mathrm{cpm}$ in the cell monolayer lysate and $2 \times 10^{6} \mathrm{cpm}$ in the culture supernatant. Thus, because the incorporation of ${ }^{35} \mathrm{~S}_{-} \mathrm{SO}_{4}$ primarily reflects glycosaminoglycan biosynthesis, the rate of GAG production seemed fourfold greater in Neu7 than in A7 under conditions of comparable protein synthesis. Furthermore, the major fraction of proteoglycans synthesized under these conditions accumulated in the culture supernatant. When immunoprecipitation experiments were performed with polyclonal anti-NG2 antibodies on ${ }^{35} \mathrm{~S}_{-} \mathrm{SO}_{4}$-labeled cultures, no significant signal could be obtained from A7, whereas Neu7 produced a polydisperse smear in the expected molecular mass range (Fig. 5). Expressing immunoprecipitated NG2 as a percentage of overall incorporation, $0.24 \%$ of incorporated ${ }^{35} \mathrm{~S}_{-} \mathrm{SO}_{4}$ was recovered from the detergent extract and $0.025 \%$ from the supernatant of Neu7. The values determined for the corresponding fractions of A7 were $0.012 \%$ and not measurable, respectively. A second cycle of immunoprecipitation 

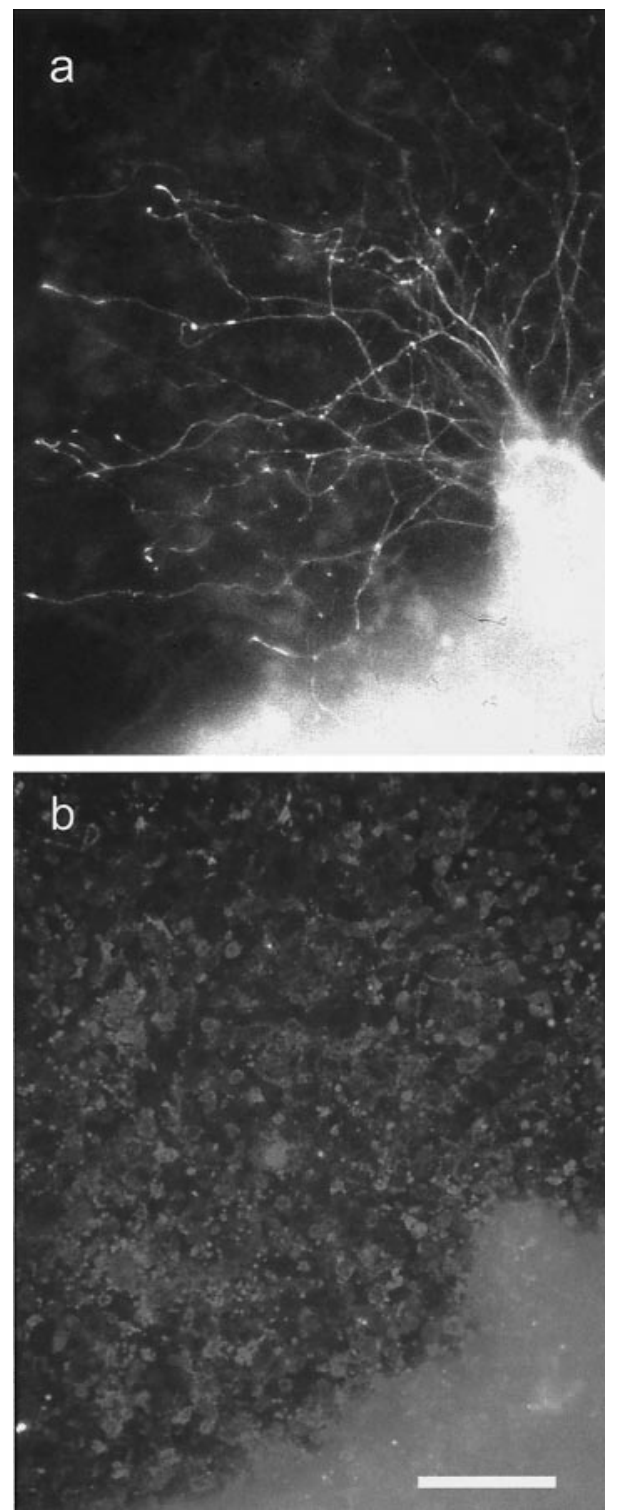

Figure 4. Axon growth from a postnatal DRG on an almost confluent culture of Neu7 cells. $a$ is a neurofilament immunostain, and $b$ is an NG2 immunostain. The axons had grown for $24 \mathrm{hr}$. Although most of the cells are stained for NG2, there is some unevenness in the intensity of NG2 staining on the Neu7 cells. However, during the $24 \mathrm{hr}$ of the assay, the cells divide, migrate, and secrete NG2 into the medium, so correlations between axon path and NG2 staining are not meaningful.

yielded $\sim 10 \%$ of the signal intensity obtained in the first cycle, indicating nearly exhaustive precipitation. Thus, on the basis of ${ }^{35} \mathrm{~S}_{-} \mathrm{SO}_{4}$ incorporation, A7 produced 20 -fold less NG2 than Neu7. To examine whether this might reflect the overall lower rate of sulfate incorporation recorded for $\mathrm{A} 7$, an immunoprecipitation experiment was performed with detergent extracts of ${ }^{35} \mathrm{~S}$ methionine-cysteine-labeled cultures in which the major fraction of NG2 was expected. In this case, a faint band of NG2 could be detected in $\mathrm{A} 7$, which reflected $\sim 0.002 \%$ of incorporated label, whereas the Neu7-derived immunoprecipitate contained $\sim 0.005 \%$ of the labeled total protein. Again, polydisperse material could be revealed in addition to a faint band, which might reflect a higher degree of GAG attachment to NG2 in the Neu7 cell line (Fig. 5). Hence, on the level of ${ }^{35} \mathrm{~S}$-methionine-cysteine-

\section{S-sulfate}
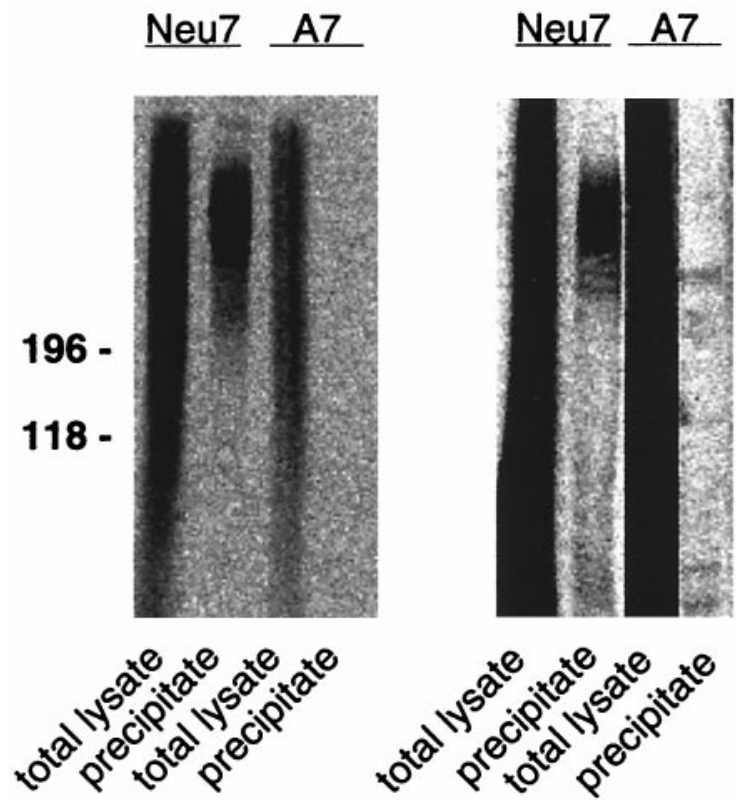

Figure 5. Immunoprecipitation of NG2 from biosynthetically labeled Neu7 and A7 cultures. Cell lines were labeled with ${ }^{35} \mathrm{~S}_{-} \mathrm{SO}_{4}$ or ${ }^{35} \mathrm{~S}$ methionine-cysteine as indicated. An aliquot of cell monolayer detergent extracts and the corresponding immunoprecipitates were resolved on neighboring lanes of a 4-10\% SDS-PAGE slab gel. Note that polydisperse NG2 can be recovered from the Neu7 lysates of both types of labeling, whereas A7 does not yield a detectable signal on ${ }^{35} \mathrm{~S}-\mathrm{SO}_{4}$ and only a faint band without smear after ${ }^{35} \mathrm{~S}$-methionine-cysteine labeling. A phosphoimager picture of the gel is shown.

labeling, the difference between the cell lines appeared less pronounced, although Neu7 still produced $\sim 2$.5-fold more NG2 than A7. However, as far as the mature GAG-attached form of NG2 is concerned, Neu7 produced by far more than the A7 cell line.

The NG2-blocking antibody increases axon growth on Neu7 cells and matrix

To ascertain whether NG2 is a functionally significant inhibitory molecule on Neu7 cells, we examined DRG axon growth on live Neu 7 cells in the presence of an NG2 function-blocking antibody. We have shown previously (Dou and Levine, 1994) that axons will grow to some extent in the presence of NG2, but growth is increased by blocking NG2 with the antibody. This antibody recognizes both the released and transmembrane forms of NG2 (Fig. 3). As a control, we used a matrix-binding polyclonal antibody to laminin. Both antibodies were present at $0.4 \mathrm{mg} / \mathrm{ml}$. Although the laminin antibody had no effect on the extent of axon growth, the presence of the anti NG2 antibody caused a large increase in axon growth (three separate assays, four wells with three DRGs per well for each condition in each assay; $p<0.001$; $t$ test) (Fig. 7a). Growth was also assayed on Neu7 extracellular matrix produced by water lysis of cells. Only $38 \%$ of explants grew axons on this matrix, but in the presence of NG2 antibody, $75 \%$ grew axons (Fig. $7 b$ ).

\section{Effects of NG2-blocking antibody and CS-56 on axon crossing of A7-Neu7 boundaries}

We have shown previously (Powell et al., 1997) that the axons growing from late embryonic cortical neurons seldom cross 


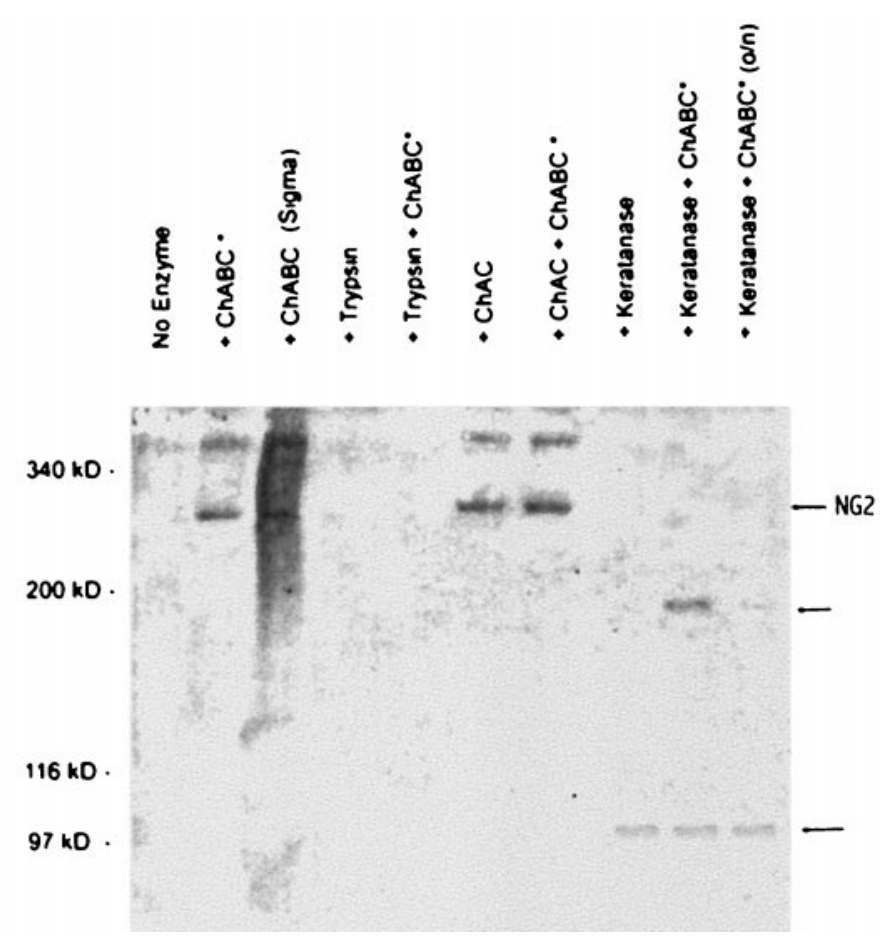

Figure 6. NG2 Western blot of Neu7 detergent lysate after digestion of samples with various enzymes. No NG2 band at $\sim 300 \mathrm{kDa}$ is seen in the absence of digestion with chondroitinase $\mathrm{ABC}$ or $\mathrm{AC}$, but after digestion with these enzymes, a sharp band is seen. Chondroitinase $\mathrm{ABC}$ and $\mathrm{AC}$ produce the same effect, and there is no additive effect. In Neu7 detergent lysate, a larger unidentified band at higher molecular weight is also seen. On digestion with keratanase, the $300 \mathrm{kDa}$ band disappears, and a new band is seen at $100 \mathrm{kDa}$. When chondroitinase $\mathrm{ABC}$ is added to the keratanase, a $200 \mathrm{kDa}$ band is seen in addition to the $100 \mathrm{kDa}$ band. Digestion overnight with keratanase and chondroitinase (right lane) leads to almost complete disappearance of the $200 \mathrm{kDa}$ band.

boundaries from A7 cells to Neu7 cells. Approximately 5\% of axons will cross from the permissive to the inhibitory cell line, the rest either turning away from the boundary or stopping at the boundary. We have also shown that digesting proteoglycans with chondroitinase and keratanase, or disrupting their synthesis with xylosides or chlorate can increase the number of axons crossing these boundaries $\sim 10$-fold to $\sim 40 \%$. A major component of the inhibitory activity that prevents axons crossing onto the inhibitory Neu7 cell line is therefore attributable to proteoglycans. In the present study, we have repeated this assay in the presence of the function-blocking NG2 antibody or the CS-56 antibody. As observed previously, in untreated cultures or in cultures treated with a control antibody, the proportion of axons crossing from A7 to Neu7 was $\sim 10 \%$. However, in the presence of anti-NG2 the proportion went up to $48 \%$ [ $p<0.001 ; t$ test (Fig. $8 a$ ), and in the presence of CS-56, the proportion went up from 16 to $42 \%$ (Fig. $8 b$ ); three independent estimations for each condition, each consisting of three coverslips with 100 or more axons counted on each coverslip); the same as we saw in previous experiments when we treated cultures with chondroitinase and keratanase. This and the result in the previous section together demonstrate that NG2 is a major component of the inhibitory proteoglycans produced by the Neu7 cell line.

We also investigated the effect of the CS-56 monoclonal antibody in this assay. This antibody binds to particular motifs in chondroitin sulfate chains (Sorrell et al., 1993). The presence of a

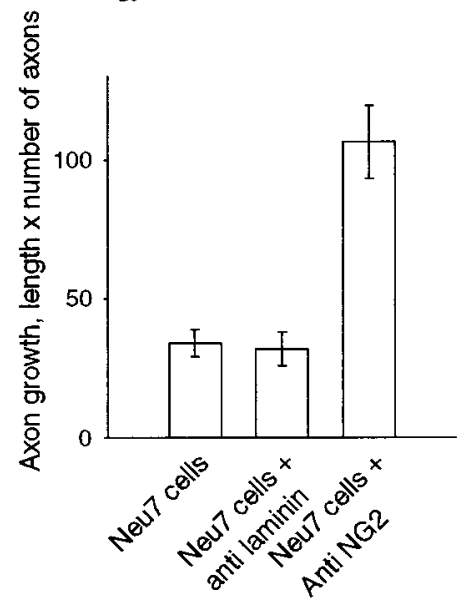

b

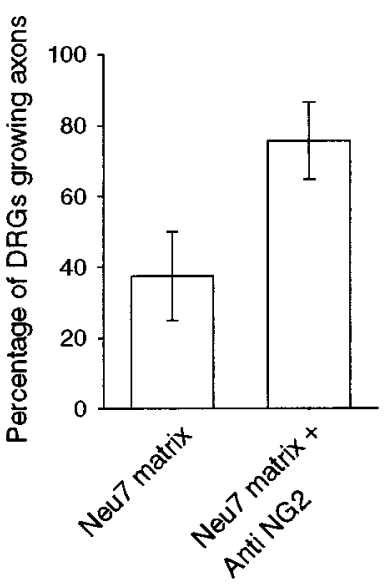

Figure 7. $a$, Axon growth from DRGs plated on Neu7 cells in the absence of antibodies, in the presence of $0.4 \mathrm{mg} / \mathrm{ml}$ of polyclonal antilaminin, or $0.4 \mathrm{mg} / \mathrm{ml}$ of polyclonal anti-NG2. The growth measurement is the number of axons growing from each DRG multiplied by the length in millimeters. NG2 antibody considerably increases axon growth, whereas the anti-laminin antibody is without effect. $b$, DRGs plated on Neu7 extracellular matrix. The proportion of DRGs producing three or more axons was counted.

CS-56 also increased the ability of cortical axons to cross from A7 cells onto Neu7 (Fig. 8).

\section{GAG lyases cleave the NG2 core protein}

Smith-Thomas et al. (1994) concluded that the inhibitory nature of Neu7 was attributable in part to a dermatan sulfate and/or keratan sulfate proteoglycans. This conclusion was based on the results of bioassays after enzymatic digestion with various GAG lyases or disruption of proteoglycan synthesis with chlorate or xylosides. Cells or cell matrix pretreated with Sigma keratanase or ChABC (which cleaves chondroitin and dermatan sulfates) or grown in the presence of chlorate or xylosides (which affect GAG sulfation and attachment to core proteins, respectively) had increased permissiveness for axon growth, and conditioned medium treated in the same way or with trypsin had reduced ability to block the axon growth-promoting effects of laminin. However, because we now have evidence that NG2, a pure chondroitin sulfate proteoglycan, is primarily responsible for the proteoglycan-mediated inhibition associated with Neu7, we suspected that some of the GAG lyase enzymes might be cleaving the NG2 core protein. This is apparently so. Using Neu7 detergent lysates, we investigated the effects of the various enzymes used in the study by Smith-Thomas et al. (1994) on the intact proteoglycan and on the core protein after treatment with protease-free $\mathrm{ChABC}$; the results are shown in Figure 6. In the absence of ChABC digestion, no NG2 band was seen, but after digestion, a band of $\sim 300 \mathrm{kDa}$ was apparent, indicating that most of the NG2 in detergent lysates possesses GAG chains. As expected, trypsin cleaved the core into such small pieces that they are not resolved in a 5\% gel. Treatment with chondroitinase AC led to the appearance of the core protein, and no further digestion occurred on the addition of ChABC. This confirms that the majority of the GAG on NG2 is chondroitin sulfate and not dermatan sulfate. After keratanase digestion, a single $100 \mathrm{kDa}$ NG2-immunoreactive species was produced, and simultaneous 

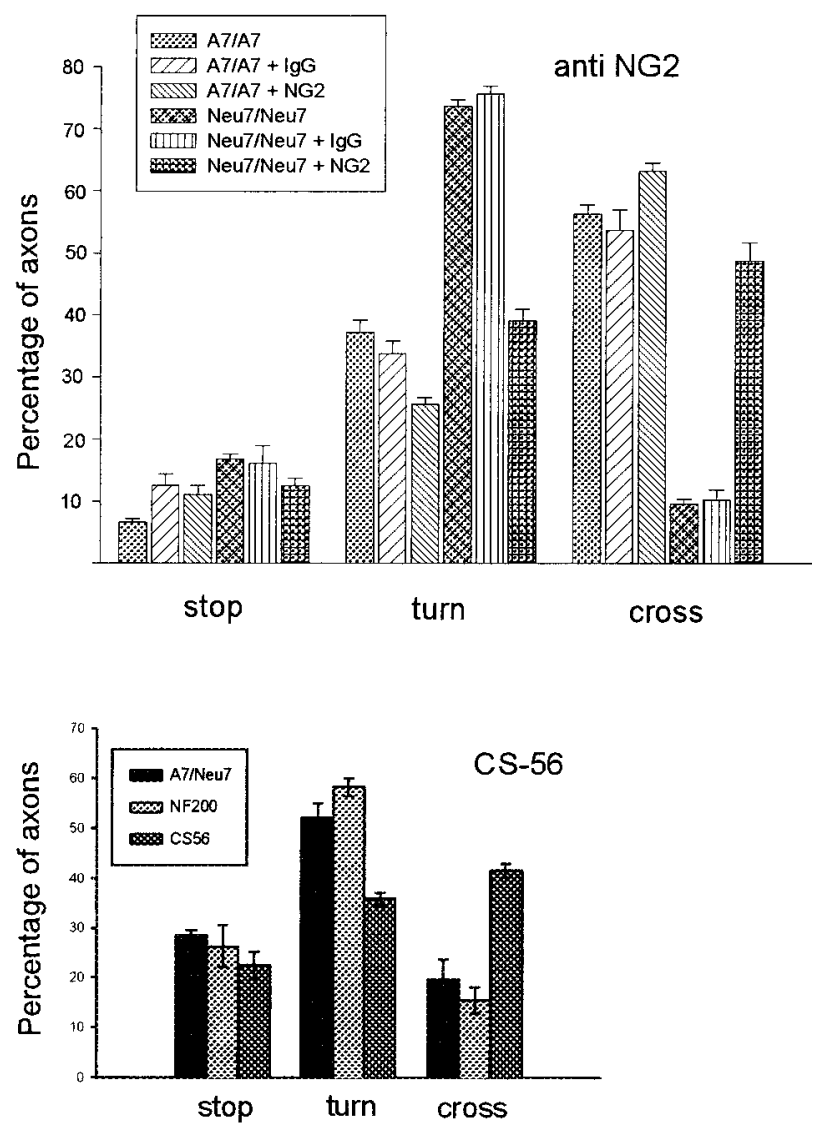

Figure 8. Anti-NG-2 significantly increases the ability of axons from cortical neurons to cross an A7-Neu7 cellular boundary. The behavior of 100 neurites per coverslip growing on A7 cells was assessed as they approached an Neu7 boundary, and classified as either stopped, turned, or crossed. In the presence of $0.2 \mathrm{mg} / \mathrm{ml}$ anti-NG2, the percentage of neurons that crossed onto Neu7 cells was increased from 10 to $48 \%$ (compare the two bars on the far right), whereas the number of neurites that turned was decreased from 75 to $39 \%$ (two bars on the right of the turn measurements). There was no change in the percentage of neurites that crossed or turned after the addition of a control IgG. The CS-56 monoclonal antibody, which binds to particular motifs in CS chains, was also tested for its ability to affect axonal boundary crossing. In the presence of CS-56, the proportion of axons able to cross from Neu7 to A7 approximately doubled.

removal of chondroitin sulfate with protease-free ChABC revealed that keratanase cleaved the intact $300 \mathrm{kDa}$ core protein, producing two proteins of $\sim 200$ and $100 \mathrm{kDa}$

Therefore, the enzyme preparations that removed the inhibition from Neu7 most effectively in our previous in vitro study are shown here to have either degraded the NG2 core or to have removed chondroitin sulfate chains.

\section{Expression of versican}

The other proteoglycan expressed at high level by Neu7 but not by A7 in our initial scan was versican. Using the $12 \mathrm{C} 5$ anti-versican monoclonal antibody (Asher et al., 1991), Western blotting showed there to be two forms of versican in the supernatant of Neu7 but not A7, 27A1, or T34.2 (Fig. 9). Versican was not detected in the detergent lysate of any of the cell lines. Although this antibody binds to the hyaluronic acid-binding region of versican and should therefore recognize all versican splice-variants, it has been shown not to cross-react with the related chondroitin

\section{versican in cell line supernatant}

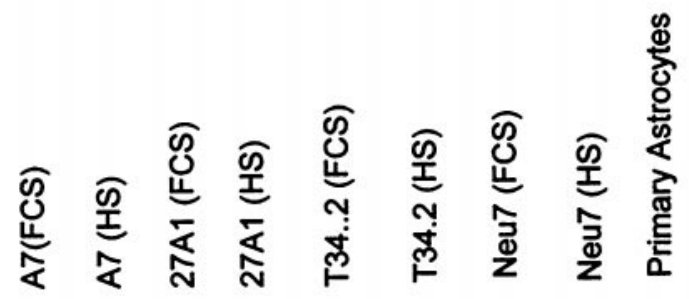

$340 \mathrm{kD}-$

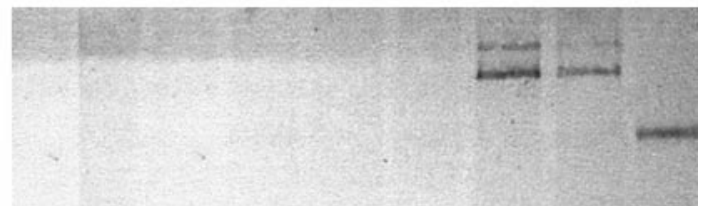

$200 \mathrm{kD}-$

Figure 9. Production of versican by cell lines grown in FCS and horse serum $(H S)$ and by primary astrocyte cultures purified by shaking off the top-dwelling cells. The Neu7 cell line produces two forms of versican, corresponding to the $\mathrm{V} 0$ and $\mathrm{V} 1$ variants, whereas the primary astrocyte cultures produce a smaller variant, corresponding to V2.

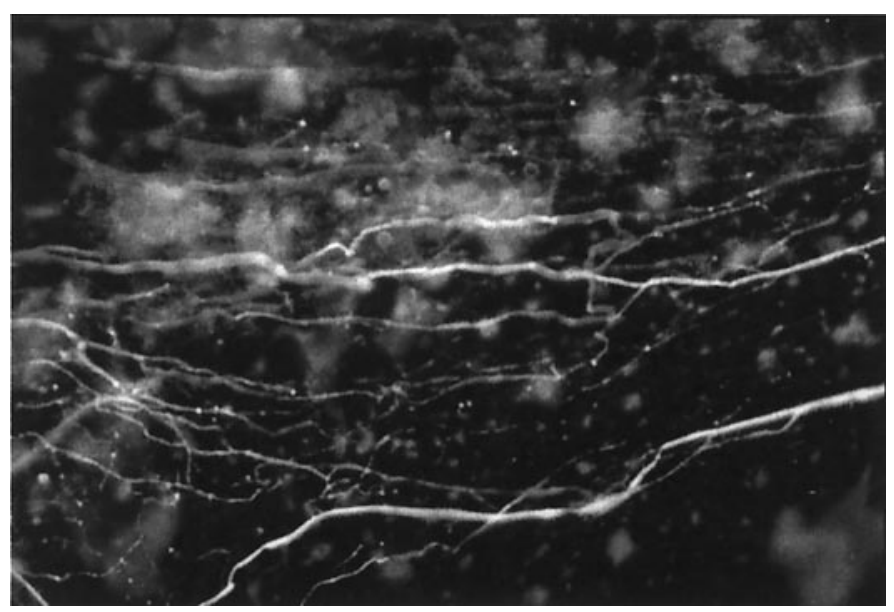

Figure 10. DRG axons growing over the surface of Neu7 cells, with the axons stained for neurofilament and the Neu7 cells stained for versican. The picture is a double exposure; axons and blobs are readily distinguishable. The versican is present in patches, with undetectable levels in between. The axons show no sign of avoiding the versican-rich areas.

sulfate proteoglycans aggrecan (Asher et al., 1995), neurocan, and brevican (R. A. Asher, unpublished observations). Interestingly, Neu7 cells produce different isoforms of versican from that seen in cultured rat cerebral cortical astrocytes (Fig. 9). Neu7 cells produce two species, both larger than the $340 \mathrm{kDa}$ marker, that probably correspond to the V0 and V1 forms of the molecule, whereas the predominant form seen in cortical astrocytes is smaller and is probably V2. Immmunocytochemistry of Neu7 monolayers showed that versican is distributed in large blobs and patches rather than being evenly spread. This distribution is different from that seen with NG2 (Fig. 10). 


\section{Axon growth on Neu7 cells in relation to versican and CS-56}

Because the distribution of versican on Neu7 monolayers is restricted to blobs with no versican in between (Fig. 10), it is possible to use this patterned surface to see whether growing axons avoid the versican-rich areas. DRGs were placed onto Neu7 monolayers, and 48-72 hr later, the cultures were double stained for versican and neurofilament. Staining for versican revealed an irregular and patchy distribution, but there was no evidence that the growing axons were avoiding these patches, nor was there any appearance of the axons having digested versican as they grew over the patches (Fig. 10). An almost identical picture was seen with the CS-56 epitope, whose distribution was patchy like that of versican, but again we saw no sign of axons avoiding these patches (data not shown).

\section{DISCUSSION}

Astrocytes are phenotypically diverse and vary in their ability to support neurite outgrowth (Grierson et al., 1990). This variability is reflected in our various cell lines (Fok-Seang et al., 1995) in which we have consistently observed that the Neu7 cell line is inhibitory to neuronal growth, whereas the A7 cell line is permissive; thus, differences between these cell lines provide an opportunity to determine which inhibitory molecules are functionally important in the context of the glial cell surface. In previous work, we have shown that much of the inhibitory activity of Neu7 cells can be ascribed to CS-PGs. Of the CS-PGs that were the subject of this study, three (NG2, versican, and the proteoglycan(s) recognized by the CS-56 antibody) were expressed at much higher levels in the inhibitory Neu7 cells than in the other cell lines.

\section{The NG2 proteoglycan}

NG2 consists of a $300 \mathrm{kDa}$ core protein bearing GAG chains composed entirely of chondroitin sulfate and is found in three forms: the full-length $300 \mathrm{kDa}$ transmembrane form, a $290 \mathrm{kDa}$ form released from the cell surface by proteolytic cleavage, and a $275 \mathrm{kDa}$ membrane-associated form, which is also produced by proteolytic cleavage but which remains associated with the cell surface (Nishiyama et al., 1995). Purified NG2 has been shown to be an inhibitor of axon growth from cerebellar granule neurons on both laminin and L1, whereas growth of sensory (DRG) axons is only inhibited on laminin. NG2 may therefore have more than one mode of action (Dou and Levine, 1994). A putative cell surface receptor has been identified on cerebellar granule neurons, although not on DRGs (Dou and Levine, 1997). NG2 has been shown to bind to collagens (types II, V, and VI), laminin, tenascin, and the PDGF receptor (Burg et al., 1996; Levine and Nishiyama, 1996; Nishiyama et al., 1996a,b). NG2 in the normal CNS is found on a population of cells thought to represent adult oligodendrocyte precursor cells (Reynolds and Hardy, 1997). After CNS damage, there is a massive recruitment of these cells to lesions within $48 \mathrm{hr}$. Numbers decline after $7 \mathrm{~d}$ but remain raised for several weeks (Levine, 1994). NG2 is also reported on astrocytes in the damaged spinal cord (Grill et al., 1998).

\section{NG2 in cell lines}

Neu7 cells produce far higher quantities of NG2 than A7, 27A1, or T34.2, producing both the $300 \mathrm{kDa}$ intact transmembrane and the $290 \mathrm{kDa}$ released forms of the molecule, both with and without CS GAG chains attached. To test whether a functionblocking NG2 antibody enhanced axon growth on Neu7 cells, we used three assays. In the first, DRG explants were grown on Neu7 cells, and the length and number of axons were measured $1 \mathrm{~d}$ later. In the second, DRG explants were cultured on Neu7 extracellular matrix. The third assay used a patterned substrate of permissive A7 and inhibitory Neu7 cells in which we have shown previously that only $5 \%$ of axons from cortical neurons cross from A7 to Neu7 but, after general disruption of all CS-PGs, this proportion goes up to $40 \%$ (Powell et al., 1997). Anti-NG2 increased growth in all assays; the addition of a blocking antibody led to a large increase in axon growth from DRG explants over the surface of Neu7 cells and matrix. In the boundary model, the proportion of cortical axons crossing from A7 cells to Neu7 was increased from $\sim 10$ to $\sim 50 \%$ by the NG2-blocking antibody. These experiments demonstrate that NG2 functions in both the regulation of axon growth and axon guidance. By anion exchange fractionation, we produced a fraction that contained NG2 without GAG chains, which was not inhibitory to axon growth, and a fraction that contained NG2 with GAG chains, which was inhibitory. This and our previous results showing that the inhibitory activity of Neu7 cells is diminished by disruption of GAG chains suggests that, in these assays, NG2 requires its CS chains to be inhibitory. However, the fractions are not pure NG2 and contain versican and possibly other proteoglycans, as well as NG2, and the less inhibitory fraction contains laminin, so it is possible that inhibitory activity attributable to the protein core of NG2 alone would have been masked in the present assays. Our results therefore show that NG2 core protein and CS chains are both involved in the inhibitory activity of Neu7 cells but do not prove that they have to be attached to one another.

To estimate the amount of NG2 production as a proportion of total proteoglycan, we undertook metabolic labeling studies with ${ }^{35} \mathrm{~S}$-methionine and ${ }^{35} \mathrm{~S}$-sulfate, using immunopreciptitation with anti NG2 to determine the proportion of labeled material represented by NG2. This experiment confirmed the observation that only Neu 7 makes the GAG-linked sulfated form of NG2, whereas Neu7 and to a lesser extent A7 make nonsulfate-labeled NG2. $\mathrm{NG} 2$ represents a minute component of the protein and a minor $(<1 \%)$ variant of the total proteoglycan synthesis. In the latter case, however, the determination of the NG2 proportion is probably a slight underestimate, because some of the ${ }^{35} \mathrm{~S}_{-} \mathrm{SO}_{4}$ label could be linked to glycolipids, particular N-linked carbohydrates, or post-translational protein modifications. Because NG2 is a small fraction of total proteoglycan, it cannot be exerting its effect by the bulk carriage of CS chains. More probably, the effect of the CS chains is achieved by their being targeted to particular molecules by specific binding of the NG2 protein core to particular sites on matrix or axonal molecules.

\section{Versican}

Versican is a large secreted hyaluronate-binding proteoglycan of the aggrecan family found in many tissues, including the CNS. It carries large amounts of CS, with attachment sites for 12-15 GAG chains. Four isoforms, V0, V1, V2, and V3, have been identified and are generated from a single gene by alternative splicing (Zimmermann and Ruoslahti, 1989; Naso et al., 1994). Versican is inhibitory to neural crest migration in vitro and present in regions avoided by migrating neural crest cells in vivo, and its upregulation in the splotch mutant mouse is associated with defective neural crest cell migration (Landolt et al., 1995; Perris et al., 1996; Henderson et al., 1997).

Our results show that Neu7 cells, but not A7, T27A1, or T34.2, produce two forms of versican that are larger than the predomi- 
nant form produced by primary astrocyte cultures. Staining Neu7 monolayers for versican revealed an irregular and patchy distribution, providing a patterned versican surface on which it was possible to look for avoidance behavior by growing axons. However, DRG axons showed no avoidance of versicanimmunoreactive patches. It would appear therefore that, in this assay, either versican is either not inhibitory, a conclusion in agreement with that of Braunewell et al. (1995), or other molecules in the patches counteract its effects.

\section{Other proteoglycans}

The CS-56 antibody is reported to bind to CS chains on proteoglycans (Sorrell et al., 1993), which are strongly upregulated in the glial scar and the distribution of which correlates well with regions inhibitory to axon growth (Davies et al., 1997). Neu7 makes much more CS-56-immunoreactive material than the other cell lines. CS-56 antibody made Neu7 cells somewhat less inhibitory in our boundary crossing assay. However, because it binds to so many CS-PGs, this effect is difficult to interpret. It is possible that Neu7 makes CS-PGs that we have yet to identify, which bind CS-56.

\section{Origin of the Neu7 cell line}

In the CNS, NG2 is found on oligodendrocyte/type 2 astrocyte progenitors (O2A cells), endothelial cells, and meningeal cells but has only been reported on astrocytes in the injured spinal cord, not in cortical lesions (Levine, 1994; Grill et al., 1998). Cells of both $\mathrm{O} 2 \mathrm{~A}$ and astrocyte lineages can produce both GFAP and $\mathrm{NG} 2$ in vitro, as does Neu7. O2A cells can give rise to type 2 astrocytes, which are positive for NG2, GFAP, and versican-like Neu7; however, they also express A2B5 antigen, which Neu7 does not. Conversely, a subpopulation of type 1 astrocytes in culture can produce NG2, as well as GFAP, when stimulated with two cytokines that are present in injury sites: FGF-2 and TGFb (P. S. Fidler and J. W. Fawcett, unpublished observations; Hinkle et al., 1998). Therefore, Neu7 may be either a type 2 (O2A-derived) astrocyte or a type 1 astrocyte that has upregulated NG2 expression.

\section{Inhibition in CNS injuries}

Three glial cell types increase in numbers in CNS injuries: astrocytes, oligodendrocyte precursors, and microglia. Microglia are probably helpful to axon growth (Rabchevsky and Streit, 1997). However, reactive astrocytes can be inhibitory to axon growth (Fawcett et al., 1989; Fawcett, 1997), and oligodendrocytes (and myelin debris) contain yet further inhibitory activity (Pesheva et al., 1993; Schwab et al., 1993; McKerracher et al., 1994; Mukhopadhay et al., 1994; Faissner 1997).

Our demonstration that cell-associated NG2 is a highly potent inhibitory molecule also focuses attention on the oligodendrocyte precursors that produce it as a third major source of inhibitory activity in the damaged CNS. NG2 is highly expressed on the fine cellular processes of these cells in CNS injuries (Levine, 1994, Keirstead et al., 1998). This increase in immunoreactivity is rapid and declines after $7 \mathrm{~d}$, so NG2 is positioned to block the earliest axon regeneration in the CNS. Neu7 cells provide an in vitro model of this process, active against axons from diverse sources.

Three cell types are therefore involved in making the CNS inhibitory to axon regeneration. Myelin debris from oligodendrocytes and NG2 from oligodendrocyte precursors are present early, and later astrocytes produce a dense glial scar containing yet more inhibitory proteoglycans. To promote regeneration in vivo, it may be necessary to manipulate all three types of inhibitory glial cell or the molecules that they produce.

\section{REFERENCES}

Asher R, Perides G, Vanderhaeghen J-J, Bignami A (1991) Extracellular matrix of central nervous system white matter: demonstration of an hyaluronate-protein complex. J Neurosci Res 28:410-421.

Asher RA, Scheibe RJ, Keiser HD, Bignami A (1995) On the existence of a cartilage-like proteoglycan and link proteins in the central nervous system. Glia 13:294-308.

Braunewell KH, Pesheva P, McCarthy JB, Furcht LT, Schmitz B, Schachner M (1995) Functional involvement of sciatic nerve-derived versican and decorin-like molecules and other chondroitin sulfate proteoglycans in ecm-mediated cell-adhesion and neurite outgrowth. Eur J Neurosci 7:805-814.

Burg MA, Tillet E, Timpl R, Stallcup WB (1996) Binding of the NG2 proteoglycan to type VI collagen and other extracellular matrix molecules. J Biol Chem 271:26110-26116.

Davies SJA, Fitch MT, Memberg SP, Hall AK, Raisman G, Silver J (1997) Regeneration of adult axons in white matter tracts of the central nervous system. Nature 390:680-684.

Dou CL, Levine JM (1994) Inhibition of neurite growth by the NG2 chondroitin sulfate proteoglycan. J Neurosci 14:7616-7628.

Dou CL, Levine JM (1997) Identification of a neuronal cell surface receptor for a growth inhibitory chondroitin sulfate proteoglycan (NG2). J Neurochem 68:1021-1030.

Faissner A (1997) The tenascin gene family in axon growth and guidance. Cell Tissue Res 290:331-341.

Faissner A, Clement A, Lochter A, Streit A, Mandl C, Schachner M (1994) Isolation of a neural chondroitin sulfate proteoglycan with neurite outgrowth promoting properties. J Cell Biol 126:783-799.

Fawcett JW (1997) Astrocytic and neuronal factors affecting axon regeneration in the damaged central nervous system. Cell Tissue Res 290:371-377.

Fawcett JW, Housden E, Smith-Thomas L, Meyer RL (1989) The growth of axons in three dimensional astrocyte cultures. Dev Biol 135:449-458.

Fok-Seang J, Smith-Thomas L, Muir E, Du J-S, Housden E, Johnson AR, Faissner A, Geller HM, Keynes RJ, Rogers JH, Fawcett JW (1995) An analysis of astrocytic cell lines with different abilities to promote axon growth. Brain Res 689:207-223.

Geller HM, Dubois-Dalcq M (1988) Antigenic and functional characterization of a rat central nervous system-derived cell line immortalized by a retroviral vector. J Cell Biol 107:1977-1986.

Grierson JP, Petroski RE, Ling DSF, Geller HM (1990) Astrocyte topography and tenascin/cytotactin expression: correlation with the ability to support neuritic outgrowth. Dev Brain Res 55:11-19.

Grill RJ, Stallcup WB, Tuszynski MH (1998) Temporal upregulation and spatial distribution of putative inhibitory and growth permissive substrate molecules in the injured adult rat spinal cord. Soc Neurosci Abstr 24:1054.

Henderson DJ, Ybot-Gonzalez P, Copp AJ (1997) Over-expression of the chondroitin sulfate proteoglycan versican is associated with defective neural crest migration in the pax3 mutant mouse (splotch). Mech Dev 69:39-51.

Hinkle DA, Harney JP, Cai A, Hilt DC, Yarowsky PJ, Wise PM (1998) Basic fibroblast growth factor- 2 and interleukin- $1 \beta$ regulate S100 expression in cultured astrocytes. Neuroscience 82:33-41.

Keirstead HS, Levine JM, Blakemore WF (1998) Response of the oligodendrocyte progenitor cell population (defined by NG2 labelling) to demyelination of the adult spinal cord. Glia 22:161-170.

Landolt RM, Vaughan L, Winterhalter KH, Zimmermann DR (1995) Versican is selectively expressed in embryonic tissues that act as barriers to neural crest cell migration and axon outgrowth. Development 121:2303-2312.

Levine JM (1994) Increased expression of the ng2 chondroitin-sulfate proteoglycan after brain injury. J Neurosci 14:4716-4730.

Levine JM, Nishiyama A (1996) The NG2 chondroitin sulfate proteoglycan: a multifunctional proteoglycan associated with immature cells. Perspect Dev Neurobiol 3:245-259.

McKeon RJ, Schreiber RC, Rudge JS, Silver J (1991) Reduction of neurite outgrowth in a model of glial scarring following CNS injury is correlated with the expression of inhibitory molecules on reactive astrocytes. J Neurosci 11:3398-3411.

McKerracher L, David S, Jackson DL, Kottis V, Dunn RJ, Braun PE 
(1994) Identification of myelin-associated glycoprotein as a major myelin-derived inhibitor of neurite growth. Neuron 13:805-811.

Morris EJ, Geller HM (1996) Induction of neuronal apoptosis by camptothecin, an inhibitor of DNA topoisomerase-I: evidence for cell-cycle independent toxicity. J Cell Biol134:757-770.

Muir D (1994) Metalloproteinase-dependent neurite outgrowth within a synthetic extracellular-matrix is induced by nerve growth-factor. Exp Cell Res 210:243-252.

Mukhopadhay G, Doherty P, Walsh FS, Crocker PR, Filbin MT (1994) A novel role for myelin associated glycoprotein as an inhibitor of axonal regeneration. Neuron 13:757-767.

Naso MF, Zimmermann DR, Iozzo RV (1994) Characterization of the complete genomic structure of the human versican gene and functional analysis of its promoter. J Biol Chem 269:32999-33008.

Nishiyama A, Lin XH, Stallcup WB (1995) Generation of truncated forms of the ng2 proteoglycan by cell- surface proteolysis. Mol Biol Cell 6:1819-1832.

Nishiyama A, Lin XH, Giese N, Heldin CH, Stallcup WB (1996a) Co-localization of NG2 proteoglycan and PDGF $\alpha$-receptor on O2A progenitor cells in the developing rat brain. J Neurosci Res 43:299-314.

Nishiyama A, Lin XH, Giese N, Heldin CH, Stallcup WB (1996b) Interaction between NG2 proteoglycan and PDGF $\alpha$-receptor on O2A progenitor cells is required for optimal response to PDGF. J Neurosci Res 43:315-330.

Perris R, Perissinotto D, Pettway Z, Bronner FM, Morgelin M, Kimata K (1996) Inhibitory effects of PG-H/aggrecan and PG-M/versican on avian neural crest cell migration. FASEB J 10:293-301.

Pesheva P, Gennarini G, Goridis C, Schachner M (1993) The F3/11 cell adhesion molecule mediates the repulsion of neurons by the extracellular matrix glycoprotein J1-160/180. Neuron 10:69-82.

Petroski RE, Geller HM (1994) Selective labeling of embryonic neurons cultured on astrocyte monolayers with 5(6)-carboxyfluorescein diacetate (CFDA). J Neurosci Methods 52:23-32.
Pindzola RR, Doller C, Silver J (1993) Putative inhibitory extracellular matrix molecules at the dorsal root entry zone of the spinal cord during development and after root and sciatic nerve lesions. Dev Biol 156:34-48.

Powell EM, Fawcett JW, Geller HM (1997) Proteoglycans provide neurite guidance at an astrocyte boundary. Mol Cell Neurosci 10:27-42.

Rabchevsky AG, Streit WJ (1997) Grafting of cultured microglial cells into the lesioned spinal cord of adult rats enhances neurite outgrowth. J Neurosci Res 47:34-48.

Reynolds R, Hardy R (1997) Oligodendroglial progenitors labeled with the $\mathrm{O} 4$ antibody persist in the adult rat cerebral cortex in vivo. J Neurosci Res 47:455-470.

Schwab ME, Kapf hammer JP, Bandtlow CE (1993) Inhibitors of neurite growth. Annu Rev Neurosci 16:565-595.

Smith-Thomas L, Fok-Seang J, Stevens J, Du J-S, Muir E, Faissner A, Geller HM, Rogers JH, Fawcett JW (1994) An inhibitor of neurite outgrowth produced by astrocytes. J Cell Sci 107:1687-1695.

Smith-Thomas L, Stevens J, Fok-Seang J, Muir E, Faissner A, Rogers JH, Fawcett JW (1995) Increased axon regeneration in astrocytes grown in the presence of proteoglycan synthesis inhibitors. J Cell Sci 108:1307-1315.

Snow DM, Letourneau PC (1992) Neurite outgrowth on a step gradient of chondroitin sulfate proteoglycan (CS-PG). J Neurobiol 23:322-336.

Snow DM, Lemmon V, Carrino DA, Caplan AI, Silver J (1990) Sulfated proteoglycans in astroglial barriers inhibit neurite outgrowth in vitro. Exp Neurol 109:111-130.

Sorrell JM, Carrino DA, Caplan AI (1993) Structural domains in chondroitin sulfate identified by anti-chondroitin sulfate monoclonal antibodies. Immunosequencing of chondroitin sulfates. Matrix 13:351-361.

Zimmermann DR, Ruoslahti E (1989) Multiple domains of the large fibroblast proteoglycan, versican. EMBO J 8:2975-2981. 